\title{
Geocement immobilization of radioactive waste ion-exchange resins
}

\author{
SHAOBIN LI ${ }^{1, \text { a }}$, HAILIN CAO ${ }^{1}$, PAVLE KRIVENKO ${ }^{2}$, OLEG \\ PETROPAVLOVSKII', LUQIAN WENG ${ }^{1}$ \\ ${ }^{1}$ Advanced Materials Research Institute, Shenzhen Academy of Aerospace Technology, The Tenth \\ Kejinan Road, High-tech Zone, Shenzhen, P.R.China \\ ${ }^{2}$ V.D.Glukhovsky Scientific Research Institute for Binders and Materials, Kiev National University of \\ Civil Engineering and Architecture, Vozdukhoflotsky prospect 31, 03680 Kiev Ukraine \\ alishaobin@chinasaat.com
}

Keywords: Geocement, immobilization, radioactive waste, ion-exchange resins

Abstract. The cementation has been the most widely used technology for immobilization of low-level nuclear wastes up to date. The increase of the amount of waste containing in a standard cementation unit is very important since it could reduce the waste disposal cost significantly, which requires an optimization of cement applied as well as immobilization technologies. This paper presented the results on developing the geocement recipe for immobilizing the low-level radioactive ion exchange resin wastes. The wastes included two types of ion-exchange resins: cation- and anion-exchange resins mixed as $2: 1$ with $\mathrm{pH}=12$ and anion-exchanged resin with $\mathrm{pH}=5$. Analysis of the obtained results suggested that the developed optimal recipe of the final product in its properties was in compliance and in some case even exceeded these set in the standards of GB 7023 and GB 14569, China.

\section{Introduction}

Current practice of radioactive waste management at nuclear power plants includes the conditioning, immobilization, for example, by cementation and placement in special containers with following disposal for long-term storage in engineered disposal facilities. For disposal of radioactive wastes of low and intermediate activity with half-life periods of $30\left({ }^{137} \mathrm{Cs}\right)$ and 29.12 years $\left({ }^{90} \mathrm{Sr}\right)$, this period is 300 years [ $1-2]$. Therefore, the processes whereby a given batch of low-level radioactive or mixed radioactive and hazardous waste is converted to a single, solid piece are needed for solidification. Prior to being solidified, the waste could be in a variety of forms and one form is the ion-exchange resin waste. Generally solidification is accomplished by mixing the waste with a solidification agent or binder. The binder forms a monolithic solid by reacting chemically with the waste, by forming microscopic cells that encapsulate the waste, or by coating and binding the individual particles. A choice of radioactive waste solidification method should provide simplicity and reliability of operations, high productivity, minimal volume, reduced radiation exposure on personnel, easiness-to-repair and low cost of equipment. Of course, of first priority are properties of solidified waste forms in order to satisfy regulatory requirements.

\section{Experimental}

The radioactive waste to be immobilized included two types of ion-exchange resins. The characteristics of ion-exchange resin are as follows: (1) cation-exchange resin and anion-exchange resin mixed as $2: 1$; (2) water content: $48.5 \%$ by mass; (3)CsNO3 content: 7.5 g/l, Sr(NO3)2 content: $12.0 \mathrm{~g} / \mathrm{l}$, boron acid content: $74.8 \mathrm{~g} / \mathrm{l}$. After mixing the ion-exchange resin pulp was allowed to mature and had the following characteristics: (1) density $(\rho)=1.18 \mathrm{~kg} / \mathrm{l}$; (2) bulk density of ion exchange resins in wet state $(\rho)=0.71 \mathrm{~kg} / \mathrm{l}$. The geocement-based grouts should meet the following requirements: (1) waste (pulp) loading - not less than $60 \%$ by volume; (2) flow ability of paste (mixture of resins and cement, or grout) $\geq 150 \mathrm{~mm}$; (3) initial setting time $\geq 2$ hours, final setting time $<24$ hours. The 
grout was prepared in a mixer of "Hobart" type. First of all, the ion-exchange resin pulp was brought into the mixer bowl, which, before its taking from a plastic container was properly mixed for proper homogenization of the resin particles in the pulp, then the geocements constituents were added and the mixture was finally mixed for $7 \mathrm{~min}$. The cylinder specimens $(\mathrm{D}=\mathrm{h}=50 \mathrm{~mm})$ were prepared from the geocement-based grouts. The specimens were placed in a laboratory climatic chamber or exiccator for further storage for 28 days after demoulding in 1-2 days. In order to determine a stability of the geocement-based grouts to water bleeding (free liquid), the cylinder specimens $(\mathrm{d}=120 \mathrm{~mm}$ and $\mathrm{h}=800 \mathrm{~mm}$ ) were prepared.

\section{Results and discussion}

The influence of quantities of the added clay component - bentonite and $\mathrm{Ca}$ - containing components $\left(\mathrm{OPC}\right.$ or $\left.\mathrm{Ca}(\mathrm{OH})_{2}\right)$, as well as types and quantity of alkaline activator $\left(\mathrm{Na}_{2} \mathrm{CO}_{3}\right)$ were studied. Test results are given in Table 1. Analysis of the study results presented in the above table allowed revealing relationships (influence of each mentioned constituent on the above listed properties).

The alkaline activator contents in the geocements should be chosen in such a way that to provide the initial setting - not earlier than after 2 hours, and final setting - not later than after 24 hours. As it follows from Tables 1, the final products met these target requirements include $6 \mathrm{CM}, 8 \mathrm{C}, 9 \mathrm{C}, 9 \mathrm{CM}$, 10C. The compressive strength was 4.5-6.4 MPa, and after7 days - 11.0 MPa (composition 10C). Evidently, a final choice can be made after completion of all scheduled testing of the final product such as free liquid, leachability, resistance to long term storage in water and so on . The clay component in the formulation of the final product can play a double role: at the stage of grout preparation - as a regulator of rheological properties, whereas at the stage of properties formation - to improve adsorption properties of the geocement matrix with regard to radionuclides. Also, in the presence of alkali it can serve as a source of formation of alkaline and alkaline earth aluminosilicate hydrates, which, as is known, affect favorably both adsorption properties and durability of the final product. The study of rheological properties of the geocement-based grouts showed that by changing the bentonite additive quantities a flowability of the geocement-based grouts could be easily dealt with. By a proper choice of the required quantity of the bentonite additive ( $4.0 \%$ by mass), the geocement-based grout with required flowability - at least $180 \mathrm{~mm}$ - was produced (composition 9CM). The $\mathrm{Ca}$ - containing component in the final product plays a double role. First of all, being present in the ion-exchange resins containing boric acid, it enters into interaction with this acid binding the boron into insoluble compounds of the $\mathrm{CaO} \cdot \mathrm{B}_{2} \mathrm{O}_{3} \cdot 6 \mathrm{H}_{2} \mathrm{O}$ type and in this way neutralizing a negative action of boron on the processes of hydration and hardening of the geocement. Secondly, the addition of OPC or $\mathrm{Ca}(\mathrm{OH})_{2}$ into the geocement composition accelerates structure-forming processes in the cement matrix, thus intensifying strength gain, especially at initial phase of hardening. The results of experiments held coincide well with this assumption. First, the final setting time of the product with the $\mathrm{Ca}(\mathrm{OH})_{2}$ meet requirement: earlier than 24 hours. Second, the compressive strength of the final product containing resin with the $\mathrm{Ca}(\mathrm{OH})_{2}$ additive is: after 28 days of hardening -not lower than $10 \mathrm{MPa}$.

With the above considerations, the results of experiments on production of the geocement-based grouts with target properties (waste (pulp) loading, flowability, setting times) and their further testing allowed to choose the following compositions for the preparation of test specimens of the final product:with the type I ion-exchange resin - compositions 9CM. 
Table 1 Composition and properties of the final products containing ion-exchange resin

\begin{tabular}{|c|c|c|c|c|c|c|c|c|}
\hline \multirow{2}{*}{\multicolumn{2}{|c|}{ Composition }} & $6 \mathrm{C}$ & $6 \mathrm{CM}$ & $7 \mathrm{C}$ & $8 \mathrm{C}$ & $9 \mathrm{C}$ & 9CM & $10 \mathrm{C}$ \\
\hline & & \multicolumn{7}{|c|}{$\%$ by weight } \\
\hline \multicolumn{2}{|c|}{ S-1 (slag, ggbs) } & 35.2 & 35.4 & 35.6 & 36.8 & 35.2 & 34.3 & 40.2 \\
\hline \multicolumn{2}{|c|}{$\mathrm{Na}_{2} \mathrm{CO}_{3}$} & 2.5 & 3.0 & 1.6 & 2.4 & 2.2 & 3.0 & 2.5 \\
\hline \multicolumn{2}{|c|}{$\mathrm{OPC}$} & 8.8 & 8.8 & 8.8 & - & - & - & - \\
\hline \multicolumn{2}{|c|}{ Bentonite } & 5.2 & 4.5 & 5.1 & 4.9 & 4.7 & 4.0 & 2.5 \\
\hline \multicolumn{2}{|c|}{$\mathrm{Ca}(\mathrm{OH})_{2}$} & - & - & - & 4.7 & 4.5 & 4.0 & 4.9 \\
\hline \multicolumn{2}{|c|}{$\begin{array}{l}\text { Ion-resin pulp (mixture of } \\
\text { cation and anion exchange } \\
\text { resin) }\end{array}$} & 42.4 & 42.4 & 41.9 & 40.1 & 43.7 & 45.0 & 41.3 \\
\hline \multicolumn{2}{|c|}{$\mathrm{H}_{2} \mathrm{O}$} & 5.9 & 5.9 & 7.0 & 11.1 & 9.7 & 9.7 & 8.6 \\
\hline \multicolumn{2}{|c|}{ Flow, mm } & 150.0 & 183.0 & 160.0 & 155.0 & 170.0 & 187 & 160.0 \\
\hline \multicolumn{2}{|c|}{$\begin{array}{l}\text { Waste (pulp) loading, \% by } \\
\text { volume }\end{array}$} & 60.2 & 60.3 & 59.2 & 54.2 & 58.3 & 60.0 & 57.0 \\
\hline \multicolumn{2}{|c|}{ Initial setting time, hr-min } & \multicolumn{7}{|c|}{ Over $2 \mathrm{hr}$} \\
\hline \multicolumn{2}{|c|}{ Final setting time, hr-min } & $\begin{array}{l}\text { Over } 24 \\
\text { hr }\end{array}$ & $\begin{array}{c}\text { Shorter } \\
\text { than } \\
22 \mathrm{hr} \\
\end{array}$ & $\begin{array}{l}\text { Over } 24 \\
\mathrm{hr}\end{array}$ & \multicolumn{4}{|c|}{ Shorter than $22 \mathrm{hr}$} \\
\hline \multirow{3}{*}{$\begin{array}{l}\text { Compressive } \\
\text { strength, } \\
\mathrm{MPa}\end{array}$} & $3 \mathrm{~d}$ & 3.2 & 4.5 & 2.2 & 6.1 & 5.3 & 5.4 & 6.4 \\
\hline & $7 \mathrm{~d}$ & 5.2 & 6.1 & 4.5 & 10.3 & 8.2 & 9.8 & 11.0 \\
\hline & $28 \mathrm{~d}$ & 7.0 & 8.1 & 7.5 & 12.8 & 10.4 & 10.8 & 13.0 \\
\hline
\end{tabular}

A preliminary study of stability of the geocement-based grouts to segregation showed that the ion-exchange resin contained in the solidified waste forms (final products), despite high flow-ability of the grouts, turned out to be homogeneously distributed over cross sections (Fig.1). Besides, the studies held with the help of an electron microscopy showed that the final products had an uniform structure in cross section with homogeneously distributed the ion-exchange resin particles in the geocements matrix, the interfacial transition zone was clear and without visible cracks (Fig 2).

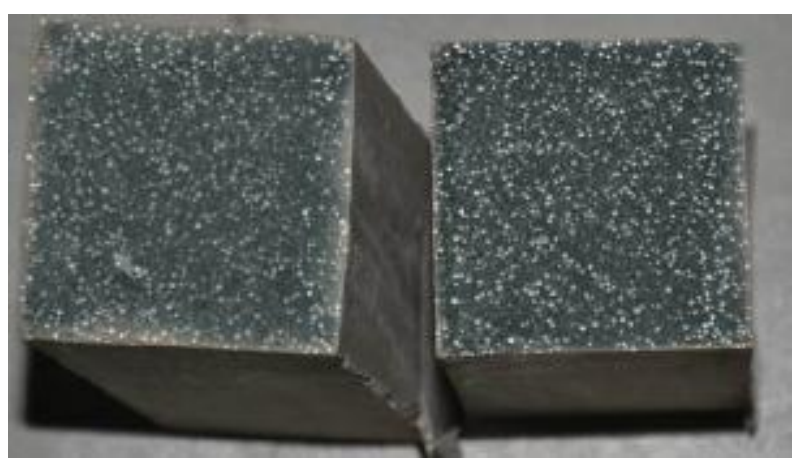

Fig. 1 Distribution of resin particles in hardened specimens(Composition 9CM) 


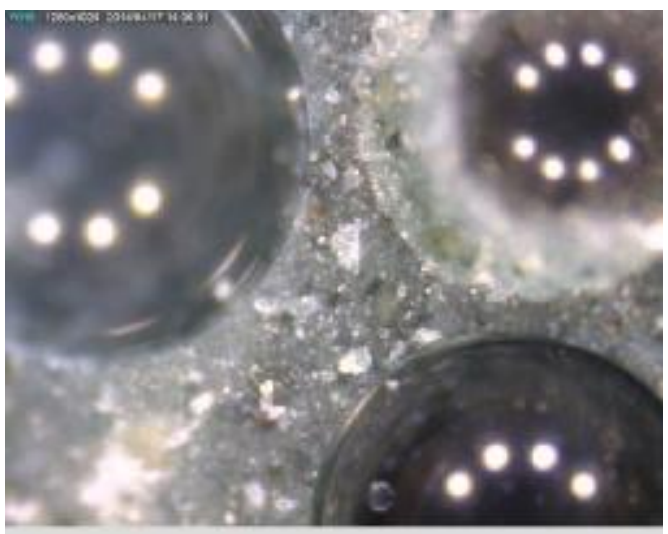

Fig. 2 Distribution of resin particles in geocement-based matrix (Composition 9CM)

The test results of the solidified body of radioactive waste immobilized by the geocement materials are given in Table 2. Also Fig 3 shows that Compositions 9CM was characterized by total absence of free liquid at 7 days age. Composition 9CM met requirements on frost resistance - loss of compressive strength are less than $25 \%$. Specially the result of radiation resistance shows that the high radiation resistance and durability (longevity, endurance) of the alkali-activated cement stone under conditions of exposure of radiation fields can be supported by the results of analysis of literary sources, in particular $[1,2]$, which stated that the long-term exposure to radiation of the alkali-activated cement stone would not harmful but on the contrary would increase its hydration degree and improve strength properties.

Table 2 Results of properties of the final product tests

\begin{tabular}{|c|c|c|c|c|c|}
\hline & $\begin{array}{c}\text { Resin } \\
\text { content, \% } \\
\text { by mass }\end{array}$ & $\begin{array}{c}\text { compressive } \\
\text { strength } \\
(\mathrm{MPa})\end{array}$ & leaching & $\begin{array}{c}\text { freeze } \\
\text { properties } \\
\text { resistance } \\
\text { ( Strength } \\
\text { changes, \% })\end{array}$ & $\begin{array}{c}\text { radiation } \\
\text { resistance } \\
(\text { Strength } \\
\text { changes, \% ) }\end{array}$ \\
\hline 9CM & 41.1 & 10.5 & $6.3 \times 10^{-3}$ & -10.3 & +0.9 \\
\hline
\end{tabular}

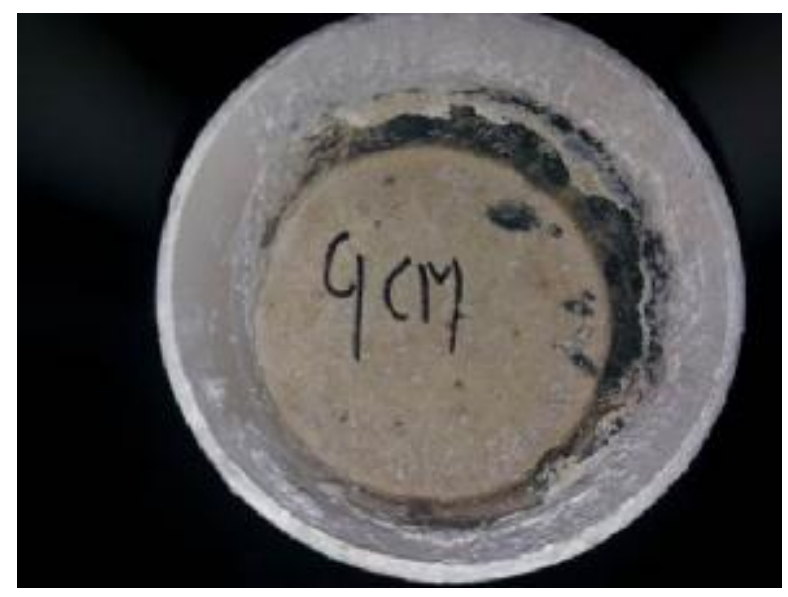

Fig 3 No free liquid at 7 days age (Compositions 9CM) 


\section{Conclusions}

The analysis of the taken results suggested that the optimal composition of geocement used for immobilizing the ion exchange resin waste was obtained and met the related requirements. In particularly Composition 9CM exhibited an excellent radiation resistance property, which is promising for practical application.

The authors are grateful for the support of Peacock Program funded by Shenzhen science and technology innovation committee.

\section{References}

[1] Petrova TM, Komokhov PG, Poltavchenko AN Problems of the durability of slag-alkali concretes during operation under long-term exposure to g-irradiation, Tez. doc. II Intern. scientific and practical. Confer. "Composite-2001. Protective Composite Materials and Technologies of the Third Millennium "." - St. Petersburg, Russia .- 2001. - P.27-28.

[2] Konovalov EE, Lastov AI, Malumyan IV Immobilization of Radioactive Waste by Curing in Geocement Stones // Obninsk Symposium of the 15th Mendeleev Congress on General and Applied Chemistry "Radioecological Problems in Nuclear Power and in Conversion of Production" - Reports of the State Scientific Center of the Russian Federation - Physics and Power Institute. - Obninsk, Russia, May 31-June 5, 1994, p.1, p.273-280 